\title{
CONTEMPORARY BASIS OF RURAL TOURISM DEVELOPMENT IN ŠUMADIJA DISTRICT
}

\author{
Nemanja Matic ${ }^{1}$, Snezana Djordjevic ${ }^{2}$, Milan Vujic ${ }^{3}$ \\ *Corresponding author E-mail: nemanjakg@yahoo.com
}

A R T I C LE I N F O

Review Article

Received: 28 June 2019

Accepted: 17 September 2019

doi:10.5937/ekoPolj1903869M

UDC 338.486/.488(497.11 Šumadija)

Keywords:

Regionalisation, innovations, tourism, rural areas,

Šumadija district, sustainable development

JEL: O18, P25, R11, Z32, Q01
A B S T R A C T

This paper aims at showing that the regionalization, innovations, smart specialization and sustainable tourism development like contemporary basis of rural tourism development can significantly contribute to increasing the competitiveness of both of the whole region and all its parts, and hence rural ones. We used several methods such as literature analysis and empirical research based on the questionnaires distributed to the stakeholders in the tourism of the Šumadija District. Our conclusion is that there is a positive attitude among the stakeholders towards creating a tourism region in the Šumadija District based on innovations, smart specialization and sustainable development. We also claim that rural tourism is a priority and that the stakeholders in the Šumadija District should focus on this type of tourism.

(C) 2019 EA. All rights reserved.

\section{Introduction}

Rural areas are usually less developed than urban ones and do not have a sufficient number of attraction, adequate infrastructure and suprastructure to attract more tourists. In practice, there are numerous examples of rural areas, where material position of population is improved by the development of rural tourism (Mariel and Sâncraiu in Romania, family farms in Finland and Poland, Latkovac, Kosjerić in Serbia) (Podovac, et al., 2019). In order to increase tourism traffic in rural areas, it is necessary to create regional tourist destinations where the development of tourism in the regional center would also encourage the development of rural tourism. In addition, innovations and modern information and communication technology (ICT) need to be applied, but also

1 Nemanja Matić, PhD student, Singidunum University, Faculty of Tourism and Hospitality Management, Danijelova 32,11000 Beograd, +38163 7512 490, nemanjakg@yahoo.com, ORCID ID: https://orcid.org/0000-0002-7908-5398

2 Snezana Djordjevic, Sveti Sava Elementary School, 6 King Milan Obrenovic Street, 34227 Batocina, Serbia, Phone +381 659908 000, Email: snezana.bat@gmail.com

3 Milan Vujic, MSc, College of Professional Studies Arandjelovac, Josifa Pancica 11, 34300 Arandjelovac, Serbia, Phone: +381 69 8449003; Email: milan.vujic@vsar.edu.rs; ORCID ID (https://orcid.org/0000-0002-5870-0224) 
the principle of sustainable development in view of the deterioration of the natural environment, as a basis for the development of tourism in the rural area. Đenadic et al. (2016) pointed out that the main strategic goals of the Serbian tourism in rural areas should be competitiveness in international market, balanced regional development, self-employment and motivating young people to stay in the countryside, permanent protection, implementing and maintaining high environmental standards, for the sake of long-term sustainable valorization of tourism potential of rural areas.

The aim of this paper is to analyze the basis for the development of rural tourism in the Šmadija district, based on regionalization, innovation, smart specialization and sustainable development. For the purpose of such an analysis, we conducted a survey of key stakeholders in the tourism of Šumadija in order to get answers to the questions how important each of the above bases is and can contribute to competitiveness of both of the whole region and all its parts, and hence rural ones. For this analysis, we will give an overview of literature, and then provide an analysis of empirical research.

\section{Context of the study}

Regionalization became the focus of research in the last two decades of the XX century, especially in the European Union. According to various theoreticians (Council of Europe and prof. Gerard; 1998; Söderbaum, 2003; Yoder, 2003; Schrijver, 2005), we may say that regionalization is a process of creating a new level in a state territorial organization, bridging national and local, establishing institutions with different degrees of responsibilities and authorities, and leading to the decentralized authority, with the aim of providing a better service with the citizens in the region.

Dawkins (2003) analyzes different theories of regional development and concludes that several factors affect the development of a region: specialization in goods that require the intensive use of that factor abundant in a region (Neoclassical trade theorists), firms will tend to locate near markets when the monetary weight of the final product exceeds the monetary weight of the inputs required to produce that product (Location theory), number and scale economies and transportation costs to markets (external economies model), proximity of a given distribution point (Models of spatial competition), combined influence of scale economies and transportation costs to markets (Central place theory), response to exogenous world demand (Export Base Theory), savings rates, population growth rates, and technological progress parameters determined outside (Neoclassical Exogenous Growth Theory), growth in developed regions through "spread" effects resulting from the diffusion of innovations into a "lagging" region (Cumulative Causation Theory), linkages between firms and industries (Growth Pole Theory) etc. Hadjimichalis and Hudson (2014) criticize neoclassical model of regional development, stating that it is based on depolitization and leads to privileges of particular socio-spatial class interests and ignores others, focuses exclusively on a few successful "super-star" regions and cities, neglects all other" ordinary" places, and bases their explanation of success mainly on internal, endogenous factors within the region, ignoring exogenous forces. These approaches ignore the regulatory role of the national 
state and EU institutions. Higgins and Savoie (2009) criticize both neoclassical and Marxist school theories stating that all scoieties live in particular places, cultures are defined in terms of space, these spaces are almost always smaller geographically than nation-state, in most countries, there are sharply differing or even conflicting interests among various societies occupying various spaces within them, economic and social interests of particular societies in particular spaces are closely tied to the dominance of particular sector of economic activity and the consequent structure of the economy and the society, people do develop strong loyalities and attachment to spaces, most people do not think of "welfare" in terms of nation states, market in fact does not work well, there is limited sense in which there is "harmony of interests" in national economy and national society etc.

Under the tourist region we imply such a spatial unit in which tourism is one of the dominant or unifying functions, while physiognomy is largely a consequence of this function (Vasović and Jovičić, 1982, pp. 12).

As for the innovations, we have to admit that various authors (Decelle, 2006; Weiermair, 2006; Hjalager, 2010; Camisón, Monfort-Mir, 2012; Carlisle, et al., 2013, Divisekera, Nguyen 2018; Hjalager, Madsen, 2018) refer to Schumpeter (1949, pp. 66), who defines innovation as presenting a new product or a production method, creating a new market or material sources, or creating new organizational structures in the industry. Hjalager and Madsen (2018) also relies on Schumpeter's deffinition, but add that innovation in tourism entails product and service, process, marketing, organizational, distribution and delivery and institutional innovations. Innovation in sustainable tourism could include aspects of visitor management, new accommodation forms and hospitality management developments, tourism's connections to conservation and protected areas, and the concept of slow tourism (Bramwell, \& Lane, 2012). Based on the views of various authors (Foray et al., 2011; European Commission, 2012, pp. 8; Charles et al., 2012; Landabaso, 2014; Foray, 2018; Hassink, \& Gong, 2019), it can be noted that smart specialization represents the focus of a particular country or region on resources that can provide sustainable innovation, research and development and ICT based competitiveness as key elements for supporting priority sectors.

Today, tourism encompasses new cultural values that are focused on the sustainable development and preservation of the environment at the international level (Redžić, 2019). Based on the definitions given in many documents and scientific papers (Bramwell, \& Lane, 1993; Liu, 2003; Middleton and Hawkins, 2011), we can conclude that the sustainable development of tourism means development with the concern for the preservation of the environment and resources to be exploited by future generations and minimizing the harmful effects of tourism development to the least extent possible.

We considered all these categories as the basis for increasing the competitiveness of tourist destinations. Ritchie and Crouch (2003. pp. 2) have defined the competitiveness of a tourist destination as a ability to increase tourism expenditure, to increasingly attract visitors while providing them with satisfying, memorable experiences, and to 
do so in a profitable way, while enhancing the well-being of destination residents and preserving the natural capital of the destination for future generations.

Different authors have expressed opinions in many scientific papers regarding the territorial coverage of Šmadija as the central region of the Republic of Serbia, which is also characteristic for legal and strategic documents. Cvijić (1966) considered that Sumadija ranges from Kopaonik and Jastrebac in the south, to the Sava and the Danube in the north, the Kolubara and Drina in the west and the Mlava and Pek in the east. According to Jovičić (1994), the Western Morava is the southern border of Šumadija, the Great Morava is the east, and the Kolubara with Suvobor its west border. The Spatial Plan of the Republic of Serbia from 1996 and the Spatial Development Strategy of the Republic of Serbia 2009 - 2012 - 2020 have stipulated that Kragujevac is a macroregional center or functional urban area - FUA that will connect all municipalities of the Šumadija district (except Arandjelovac). According to the Regional Spatial Plan for the area of the Šmadija, Pomoravlje, Raška and Rasina administrative district (2014), a map referring to tourism and protection of the area is given, where the socalled Šumadija tourist belt is defined - Arandjelovac, Topola, Kragujevac. In the above document, the FUA were also provided, and one of them is Kragujevac, which connects the municipalities of Knić, Batočina and Rača.

In the research done by Živanović and Djordjevic (2012), based on three criteria for defining functional urban areas such as daily migration (examination of the work center determined by the influence of the functions of the centers of work on the daily mobility of the population), temporal isochrone (30 minutes or 45 minutes isochrone of the urban center is one of the ways of determining the boundaries of its gravitational field, that is, the sphere in which its effects are the most significant) and spatial continuity, there has come to the conclusion that in the FUA Kragujevac, besides all the settlements of that municipality, the entire municipality of Batočina and almost Knić is included, while the surrounding municipalities with only a small number of settlements are included in the territorial coverage of the defined FUA. The Šmadija district is administratively encircled by the Decree on Administrative Districts and consists of the City of Kragujevac and 6 municipalities: Aranđelovac, Topola, Batočina, Lapovo, Knić and Rača (Decree on administrative districts, 15/2006).

In the Tourism strategy of the Republic of Serbia, 2005, it is envisaged that the Sumadija district should be a part of the Southwest Cluster, as one of the four clusters within the Republic of Serbia. It is noted that the key tourist products of this cluster are events, mountains and lakes, health and rural tourism (Tourism strategy of the Republic of Serbia, 2005, pp. 148). In the Tourism Development Strategy of the City of Kragujevac 2015-2020, in the segment discussing aspects of tourism on the territory of the city, there are circular tours that include destinations such as Knić, Rača, Topola, Batočina, Lapovo, Rekovac and Despotovac. This tells us that the stakeholders in the tourism of the City of Kragujevac are aware that the tourist offer should be expanded also by the attractions from the surrounding municipalities belonging to the Sumadija and Pomoravlje district. 


\section{Possibilities for development of different forms of tourism in the rural areas of the Šumadija district}

Rural tourism represents a complex multidimensional activity, which includes farm holidays, but also includes breaks related to special interests in nature, ecotourism, hiking, climbing and riding, adventures, sports and health tourism, hunting and fishing, educational trips, art and heritage tourism, and also ethnic tourism in some areas (Lane, 1994). Roberts and Hall (2001, pp. 15) state the following tourism forms regarding rural areas: agrotourism, farm toruism, wilderness and forest tourism, green tourism, ecotourism. We can conclude that various tourism types can be linked to rural tourism:

- Cultural tourism involves the movement of people essentially from cultural motifs such as study trips, artistic performance and other cultural tours, travel to the festival and other cultural events, visits to places and monuments, travel for the study of nature, folklore, art, or pilgrimage (Sigala, \& Leslie, 2005, pp. 7) and MacDonald and Jolliffe (2003) define cultural rural tourism as a distinct rural community with its own traditions, heritage, arts, lifestyles, places, and values as preserved between generations.

- $\quad$ Gastronomy - promoting culinary tourism in agri-tourism represents a winning strategy for the development of the whole economy of rural areas (Testa, et al.. 2019),

Ecotourism, as part of the tourist offer of rural areas, implies responsible travel to natural areas where the environment is protected, improves the well-being of the local population and includes interpretation and education (https://ecotourism.org/whatis-ecotourism/),

- Wine tourism can be defined as a visit to vineyards, wineries, wine festivals and wine exhibitions, where wine tasting and/or experiences related to the characteristics of wine regions are the main motivational factor for visitors (Hall, 1996).

- $\quad$ Tourism of special interest includes tourist trips motivated by special interests for particular attractions and activities, such as: sports, untouched nature, traditional crafts, wellness, culture, rural tourism, events, festivals, nautics etc. (Jovanović, 2013, pp. 1).

- $\quad$ Religious tourism is special tourist activity oriented by religious culture, with the help of specific ecocultural environment and it refers to such special touristic activities as worshipping, research, sightseeing, and culture which stimulate travel by both religious followers and lay tourists (Mu. et al, 2007).

In the rural area of the Šumadija district there are many tourist attractions that can represent the unique tourism product of the tourist region Sumadija, which is the basis for the development of rural tourism. The municipalities that are distinguished by the development of rural tourism in the Šumadija district are Knić (villages Borač, Žunje, Grabovac, Čestin etc.), Aranđelovac (villages Garaši, Vrbica, Orašac), but also villages in the vicinity of Kragujevac (Stragari, Vlakča, Čumić, Dulene, Veliki Šenj, Kutlovo, Masloševo etc.) (http://gtokg.org.rs/srb/seoski-turizam-sela/) and Topola (the foothill of Rudnik). Dimitrovski et al. (2012), having examined the providers of tourism services 
in Gruža (the Municipality of Knić), concluded that they agreed that rural tourism increases the income to the village, reduces migration to cities, increases employment in villages, increases the production of organic food, contributes to the cultural life of the countryside, as well as national and cultural identity.

Many cultural and historic tourist attractions are located in the rural area of Sumadija District. It is known that the First Serbian uprising started in Orašac (near Arandjelovac) and it can be said that this is the place of the cradle of the modern Serbian state, in the village of Viševac (the municipality of Rača) there is a memorial complex dedicated to Karadjordje, since he was born there; in the municipalities Knić and Kragujevac are the ruins of several medieval towns (Borač and Srebrnica), in the village of Gradac (in the municipality of Batočina) there are remains of a medieval town and an archaeological site where bones of extinct animals (mammoths), parts of human fossils were found, and also on that locality also there is a cave that testifies to the culture of the primitive man, as well as the necropolis with the graves from the Roman times (Sustainable Development Strategy of Batočiina Municipality 2017-2022, pp. 8). In the municipality of Rača a log cabin church stands out (proclaimed a cultural monument of special importance), the Turkish dormitory and the house of the Duke of Pavle Cukić (Miličević et al., 2015).

The gastronomic offer in many rural tourism capacities in Šumadija plays an important role in attracting tourists and is part of the cultural identity of this part Serbia. In many rural areas, there are many events that complement the tourist offer of the villages of Sumadija.

In Šumadija, a great number of locations and destinations can be suitable for ecotourism. First of all, in the municipality of Knić (Borački Karst and the surroundings of Gruža Lake) in the municipality of Arandjelovac (Bukulja and Venčac) and in the vicinity of Kragujevac (surroundings of Stragar).

Topola and Arandjelovac are located on the Serbian wine route. In Topola, the most important wine tourism capacities are the Royal Winery (the endowment of King Petar from 1930) and the Museum of Wine and Vineyards, PIC “Oplenac”, Aleksandrović and Arsenijević winery in the village of Vinča (near Topola) and winery from the village Lipovac "Rogan" and "Delena" (https://topolaoplenac.org.rs/oplenacki-put-vina/). In the Municipality of Arandjelovac, from the capacity of wine tourism, we can list "Wine cellar Grb "and" Wine cellar Vrbica" in the village of the same name (https://www. putvinasrbije.rs/put-vina-srbije-sumadija/).

In the Šumadija district there are several locations suitable for the development of fishing tourism, such as Lake Gružan in the municipality of Knić, the Great Morava, flowing through the municipalities of Batočina and Lapovo, Šumarice Lake and Grošnica Lake near Kragujevac and Garaš Lake near Arandjelovac. As for hunting tourism, there are a number of hunting sites and hunting associations in the Šumadija district that could contribute to the development of this type of tourism, such as the "Gruža" hunting ground in the Knić municipality, "Šumadija" and "Lepenica" near Kragujevac (http:// gtokg.org.rs/srb/lov-i-ribolov/), "Srebrnica" near Stragari, "Jelen" and "Karađorđe" 
near Topola (https://topolaoplenac.org.rs/lovni-turizam/), "Rogot" in the municipality of Batočina (Sustainable Development Strategy of Batočiina Municipality 2017-2022, pp. 69), "Gradište" near Rača which manages the Bukovac hunting ground (http:// tor.rs/sr/lovni-turizam/) and "Bukulja" near Arandjelovac (Sustainable Development Strategy of Aranđelovac Municipality 2016-2021. year, pp. 93).

Many mountains in the Šumadija district can serve for the purpose of sports and tourism of special interests such as Rudnik, Bukulja and Venčac, Gledić mountains and Kotlenik.

In Knić municipality on Gruža Lake there are possibilities for sport and recreation, such as rowing (arranged rowing trails and infrastructure for accessing the lake and hangar for sporting equipment) (Sustainable Development Strategy of Knić Municipality 2010 - 2020. year, pp. 31), trekking, hiking etc. In all other municipalities, there are a large number of promenades, parks, sports facilities and centers that offer tourists the opportunity to engage in sports and recreation.

Today, religious tourism is closely linked to leisure and cultural tourism (Rinschede, 1992). There are a large number of monasteries and churches in the rural area of Šumadija district (Petkovica, Voljavča, Blagovestenje near Stragar, Divostin and Drača in the villages with the same name, Raletnac, Denkovac and Sarinac in the village of Velike Pčelice, Nikolje in the village of Donja Šatornja, Brezovac in the village of the same name etc.) providing basis for the development of religious tourism.

\section{Materials and methods}

Research on the development of tourism in the rural area of the Sumadija district based on regionalization, innovation, smart specialization and sustainable development is based on surveying stakeholders who are directly or indirectly related to tourism: employees in tourist organizations in all municipalities of the Šumadija district, employees in catering (hotels, hostels, villas, restaurants), academic public (university professors and students of doctoral studies at higher education institutions - Faculty of Economics Kragujevac, Faculty of Tourism and Hotel Management in Vrnjačka Banja, and Arandjelovac High School of Vocational Studies), as well as employees in travel agencies. The survey was conducted in the period from September 2018 to January 2019, and the SPSS 19 program was used for the processing of statistical data. Our research has been conducted as internet survey and printed questionnaires distributed to the stakeholders via email or directly.

The questionnaire for the mentioned stakeholders consisted of 6 parts. The first part refers to the general data on the sample (gender, age, education, representative of different groups of stakeholders), the second part covering 5 questions (claims) refers to regionalization in tourism, the third group consists of six questions on competitiveness, fourth group consists ICT-related issues as the basis for innovation and smart specialization, the fifth group consists claims relating to sustainable development and the sixth group are claims referring to tourism specialization. To examine the different stakeholders and their views on all of the above-mentioned groups of questions (except 
for general information about respondents), we used the five-level Likert Scale, where respondents had the opportunity to circle only one of the offered assessments. The survey included basic statistical analyzes of frequency, mean and standard deviation (descriptive statistics) in order to see the attitude of stakeholders regarding the development of tourism in the rural area of the Sumadija district based regionalization, innovation, sustainable development and smart specialization.

After the basic statistic analysis, the ANOVA test (univariate variance analysis) was applied to determine the significance of the differences between several dependent variables and an independent variable, with the independent variables being the four aforementioned groups of respondents, while the dependent were the stated claims (questions).

Following these analyzes, a factorial analysis was also carried out in the SPSS to define a smaller number of groups of factors and see how each of these groups explains the variance. Based on factorial analysis, we have identified how stakeholders are interested in issues of regionalization, competitiveness, innovation, sustainable development and specialization in tourism, and which of these areas is considered a priority for the development of tourism in Šumadija region. Particular attention was paid to the level of prioritization of different types of tourism characteristic of rural areas (rural tourism, tourism of special interests, cultural tourism), as well as the importance of sustainable development of tourism as a basis for the development of this type of industry in the rural area. A total of 145 respondents were interviewed in total.

\section{Results and discussion}

Based on the research we obtained data related to descriptive statistics. After that, we conducted the ANOVA test. First, we examined the homogeneity of the variance to see if the ANOVA test can be applied to the above claims. Based on the homogeneity test of the variance, three claims did not pass the test, and we proceeded to a more robust Welch equation test of arithmetic means. On the basis of this test, it was established that the claim relating to built and cultural tourist attractions is the only one that does not fulfill the test of equality of arithmetic means and a special post-hoc test will be performed for it.

Table. 1. Descriptive statistics and results of ANOVA test (Sig.)

\begin{tabular}{|c|l|c|c|c|c|}
\hline No. & \multicolumn{1}{|c|}{ Claim (question) } & N & M & SD & $\begin{array}{c}\text { ANOVA } \\
\text { (Sig.) }\end{array}$ \\
\hline $\mathbf{1}$ & $\begin{array}{l}\text { Šmadija is a spatial entity with appropriate natural and } \\
\text { created tourist values in which a unified regional tourist } \\
\text { product can be formed. }\end{array}$ & $\mathbf{1 4 5}$ & $\mathbf{4 , 2 3}$ & $\mathbf{0 . 8 0 8}$ & $\mathbf{0 . 0 2 9}$ \\
\hline 2 & $\begin{array}{l}\text { Destinations in Šumadija will be more competitive if they } \\
\text { function as a special regional tourist destination (RTD). }\end{array}$ & 145 & 3.77 & 1.118 & 0.250 \\
\hline 3 & $\begin{array}{l}\text { The promotion of Šumadija's destinations and attractions } \\
\text { would be more successful if Šumadija would be promoted as } \\
\text { a special tourist region. }\end{array}$ & 145 & 4,07 & 1,032 & 0.382 \\
\hline
\end{tabular}




\begin{tabular}{|c|c|c|c|c|c|}
\hline 4 & $\begin{array}{l}\text { If Šumadija could be constituted as a separate tourist } \\
\text { region, it would be easier to obtain the EU funds or other } \\
\text { investments in tourism. }\end{array}$ & 145 & 3.99 & 1.034 & 0.650 \\
\hline 5 & $\begin{array}{l}\text { The Tourist Organization (TO) Kragujevac helps and } \\
\text { promotes all other destinations in the Šumadija district }\end{array}$ & 145 & 2.93 & 1.153 & 0.999 \\
\hline 6 & $\begin{array}{l}\text { Natural tourist attractions (mountains, rivers, lakes, parks, } \\
\text { and landscapes). }\end{array}$ & 145 & 3.59 & 0.954 & 0.006 \\
\hline 7 & $\begin{array}{l}\text { Built and cultural tourist attractions (museums, theaters, } \\
\text { galleries, concerts, monuments, churches, monasteries, } \\
\text { fairs and congresses facilities etc.) }\end{array}$ & 145 & 3.41 & 1.083 & $\mathbf{0 . 0 2 9}$ \\
\hline 8 & Quality of tourist facilities (hotels, hostels, restaurants, etc.). & 145 & 3.03 & 1.017 & $\mathbf{0 . 0 0 7}$ \\
\hline 9 & Traffic infrastructure and availability of tourist attractions. & 145 & 2.59 & 1.103 & 0.012 \\
\hline 10 & The employees in the tourism and hospitality industry. & 145 & 3.05 & 0.967 & 0.050 \\
\hline 11 & Competitiveness of prices in tourism. & 145 & 3.23 & 0.979 & 0.034 \\
\hline 12 & $\begin{array}{l}\text { The information on the website of the Tourist Organization } \\
\text { of the City of Kragujevac (gtokg.org.rs) is of help to tourists } \\
\text { who visit this tourist region. }\end{array}$ & 145 & 3.27 & 1.029 & 0.149 \\
\hline 13 & $\begin{array}{l}\text { Information on the websites of other Tourism Organizations } \\
\text { in Šumadija (Arandjelovac, Topola, Rača, Knić, Lapovo, } \\
\text { Batočina) are of help to tourists who visit this tourist region. }\end{array}$ & 145 & 2.98 & 0.982 & 0.202 \\
\hline 14 & $\begin{array}{l}\text { Catering companies (hotels, hostels, restaurants, clubs) in } \\
\text { Šmadija are present on relevant tourist sites (booking.com, } \\
\text { www.tripadvisor.com, etc.). }\end{array}$ & 145 & 3.24 & 0.974 & 0.066 \\
\hline 15 & $\begin{array}{l}\text { Catering companies (hotels, hostels, restaurants, etc.) of } \\
\text { Šumadija have good websites. }\end{array}$ & 145 & 3.06 & 0.864 & 0.600 \\
\hline 16 & $\begin{array}{l}\text { The presence of catering companies (hotels, hostels, } \\
\text { restaurants, clubs) of Šumadija on key social networks is } \\
\text { good and it helps to increase tourist traffic. }\end{array}$ & 145 & 3.21 & 0.873 & 0.641 \\
\hline 17 & $\begin{array}{l}\text { Tourism in Šumadija contributes to the preservation of } \\
\text { the environment. }\end{array}$ & 145 & 2.66 & 0.966 & 0.003 \\
\hline 18 & $\begin{array}{l}\text { Tourism in Sumadija contributes to the development of the } \\
\text { entire economy. }\end{array}$ & 145 & 3.18 & 0.998 & 0.109 \\
\hline 19 & Tourism in Šumadija contributes to higher employment. & 145 & 3.13 & 1.062 & 0.070 \\
\hline 20 & $\begin{array}{l}\text { Tourism in Šumadija contributes to a higher living } \\
\text { standard of the population. }\end{array}$ & 145 & 2.97 & 1.127 & $\mathbf{0 . 0 3 4}$ \\
\hline 21 & $\begin{array}{l}\text { Tourism in Šumadija contributes to the preservation of } \\
\text { social values and traditions. }\end{array}$ & 145 & 3.62 & 0.986 & 0.008 \\
\hline 22 & $\begin{array}{l}\text { New knowledge, technologies, skills and training are } \\
\text { available to tourists in Šumadija. }\end{array}$ & 145 & 2.94 & 1.022 & 0.022 \\
\hline 23 & Business tourism (MICE). & 145 & 3.63 & 1.026 & 0.323 \\
\hline 24 & $\begin{array}{l}\text { Cultural tourism (monasteries, churches, historical sites, } \\
\text { museums, exhibitions, etc.). }\end{array}$ & 145 & 4.12 & 0.904 & 0.366 \\
\hline 25 & Rural tourism. & 145 & 3.85 & 1.002 & 0.452 \\
\hline 26 & Health and wellness tourism (spa and healing tourism). & 145 & 3.59 & 1.045 & 0.665 \\
\hline 27 & City-break tourism and events (festivals, circular tours, etc.). & 145 & 3.78 & 0.946 & 0.070 \\
\hline 28 & $\begin{array}{l}\text { Mountain, sport and tourism of special interests (hunting, } \\
\text { fishing, recreation, wine tourism etc.). }\end{array}$ & 145 & 3.94 & 0.963 & 0.726 \\
\hline
\end{tabular}

$\mathrm{N}$ - number of stakeholders, M - Mean, SD - Std. Deviation

Source: Authors, based on research 
The first thing we can conclude on the basis of the obtained results in the Table 1 . is that the stakeholders who have been interviewed agree and support the idea of establishing Sumadija as a tourist region, because in the claim that Šmadija is a spatial entity with corresponding natural and created tourist values in which unified the regional tourism product mean $(\mathrm{M}=4.23)$ is the highest in relation to all other claims. Further, claims related to the establishment of Sumadija as a tourist region have the highest means compared to all other claims.

The claims relating to competitiveness elements have relatively low means, suggesting that stakeholders consider the key competitiveness elements to be at a low level in the Šumadija district. The highest means have natural tourist attractions and the lowest the infrastructure. Claims related to ICT and Sustainable Development have relatively low means, and it is especially worrying that the claim that tourism in Šumadija contributes to the preservation of the environment has the lowest arithmetic mean of all other claims in the whole questionnaire. The views of stakeholders regarding tourism specialization show that cultural tourism, mountain, sports and tourism of special interest and rural tourism have the highest average ratings.

Based on the ANOVA test, we can conclude that in ten claims (questions) there is no agreement between the respondents. For these claims, we need to do additional post hoc LSD tests, to determine the exact group of respondents that has a difference in stances related to regionalization, competitiveness, ICT, sustainable development and specialization.

Table 2. Post hoc LSD test

\begin{tabular}{|c|c|c|c|}
\hline Dependent Variable & (I) Representative & (J) Representative & Sig. \\
\hline \multirow{3}{*}{$\begin{array}{l}\text { Šmadija is a spatial unit ... in which a unified } \\
\text { regional tourism product can be formed. }\end{array}$} & Academic public & Employees in TO & 0.036 \\
\hline & Academic public & Employees in HI & 0.038 \\
\hline & Academic public & Employees in TA & 0.004 \\
\hline \multirow{3}{*}{$\begin{array}{l}\text { Natural attractions (parks, rivers, lakes, } \\
\text { mountains, climate). }\end{array}$} & Academic public & Employees in TO & 0.009 \\
\hline & Academic public & Employees in HI & 0.039 \\
\hline & Academic public & Employees in TA & 0.001 \\
\hline \multirow{3}{*}{ Quality of facilities in tourism. } & Employees in TA & Employees in TO & 0.012 \\
\hline & Employees in TA & Employees in HI & 0.001 \\
\hline & Employees in TA & Academic public & 0.012 \\
\hline \multirow{3}{*}{ Traffic infrastructure. } & Academic public & Employees in TO & 0.28 \\
\hline & Academic public & Employees in HI & 0.012 \\
\hline & Academic public & Employees in TA & 0.003 \\
\hline \multirow{3}{*}{$\begin{array}{l}\text { The employees in the tourism and hospitality } \\
\text { industry. }\end{array}$} & Employees in $\mathrm{HI}$ & Employees in TO & 0.128 \\
\hline & Employees in $\mathrm{HI}$ & Academic public & 0.128 \\
\hline & Employees in $\mathrm{HI}$ & Employees in TA & 0.006 \\
\hline \multirow{3}{*}{ Competitiveness of prices in tourism. } & Employees in TA & Employees in TO & 0.053 \\
\hline & \begin{tabular}{|l|} 
Employees in TA \\
\end{tabular} & Employees in $\mathrm{HI}$ & 0.011 \\
\hline & Employees in TA & Academic public & 0.013 \\
\hline \multirow{3}{*}{$\begin{array}{l}\text { Tourism in Sumadija contributes to the } \\
\text { preservation of the environment. }\end{array}$} & Employees in HI & Employees in TO & 0.024 \\
\hline & Employees in TA & Employees in TO & 0.000 \\
\hline & Employees in TA & Academic public & 0.040 \\
\hline
\end{tabular}




\begin{tabular}{|l|l|l|c|}
\hline \multicolumn{1}{|c|}{ Dependent Variable } & \multicolumn{1}{|c|}{$(\mathbf{I})$ Representative } & \multicolumn{1}{|c|}{$(\mathbf{J})$ Representative } & Sig. \\
\hline \multirow{2}{*}{$\begin{array}{l}\text { Tourism in Šumadija contributes to the greater } \\
\text { living standard of the population }\end{array}$} & Academic public & Employees in TO & 0.037 \\
\cline { 2 - 4 } & Academic public & Employees in HI & 0.042 \\
\cline { 2 - 4 } & Academic public & Employees in TA & 0.004 \\
\hline \multirow{2}{*}{$\begin{array}{l}\text { Tourism in Šumadija contributes to the } \\
\text { preservation of social values and tradition. }\end{array}$} & Academic public & Employees in TO & 0.032 \\
\cline { 2 - 4 } & Academic public & Employees in HI & 0.032 \\
\cline { 2 - 4 } & Academic public & Employees in TA & 0.001 \\
\hline \multirow{2}{*}{$\begin{array}{l}\text { New knowledge, technologies, skills and } \\
\text { training are available to tourists in Šumadija. }\end{array}$} & Employees in TA & Employees in TO & 0.022 \\
\cline { 2 - 4 } & Employees in TA & Employees in HI & 0.006 \\
\cline { 2 - 4 } & Employees in TA & Academic public & 0.015 \\
\hline
\end{tabular}

Note: Employees in HI - Employees in the hospitality industry, Employed in TA - Employees in the Travel Agencies, Employed in TO - Employees in the Tourism Organisations

Source: Authors, based on research

We see in the previous table that the LSD test shows that there is a disagreement between the academic public and the other three stakeholder groups about the claim that Šumadija is a spatial entity ... in which a unified regional tourism product can be formed. However, in order to make the final conclusions we have to look at the data from descriptive ANOVA test statistics.

Table 3. Descriptive statistics - ANOVA test

\begin{tabular}{|c|c|c|c|}
\hline Claims & Stakeholders & \multirow{2}{*}{$\frac{\mathbf{N}}{30}$} & \multirow{2}{*}{$\frac{\mathbf{M}}{4.17}$} \\
\hline \multirow{5}{*}{$\begin{array}{l}\text { Sumadija is a spatial entity with appropriate natural and } \\
\text { created tourist values in which a unified regional tourist } \\
\text { product can be formed. }\end{array}$} & Employees in TO & & \\
\hline & \begin{tabular}{|l|} 
Employees in HI \\
\end{tabular} & 47 & 4.21 \\
\hline & Academic public & 30 & 4.60 \\
\hline & Employees in TA & 38 & 4.03 \\
\hline & Total & 145 & 4.23 \\
\hline \multirow{5}{*}{ Natural attractions (parks, rivers, lakes, mountains, climate). } & Employees in TO & 30 & 3.43 \\
\hline & Employees in HI & 47 & 3.62 \\
\hline & Academic public & 30 & 4.07 \\
\hline & Employees in TA & 38 & 3.29 \\
\hline & Total & 145 & 3.59 \\
\hline \multirow{5}{*}{ Quality of facilities in tourism. } & Employees in TO & 30 & 3.17 \\
\hline & Employees in HI & 47 & 3.26 \\
\hline & Academic public & 30 & 3.17 \\
\hline & Employees in TA & 38 & 2.55 \\
\hline & Total & 145 & 3.03 \\
\hline \multirow{5}{*}{ Traffic infrastructure. } & Employees in TO & 30 & 2.77 \\
\hline & Employees in HI & 47 & 2.43 \\
\hline & Academic public & 30 & 3.07 \\
\hline & Employees in TA & 38 & 2.26 \\
\hline & Total & 145 & 2.59 \\
\hline
\end{tabular}




\begin{tabular}{|c|c|c|c|}
\hline \multicolumn{2}{|r|}{ Stakeholders } & \multirow{2}{*}{$\mathbf{N}$} & \multirow{2}{*}{$\begin{array}{c}\mathbf{M} \\
3.00\end{array}$} \\
\hline \multirow{5}{*}{ The employees in the tourism and hospitality industry. } & Employees in TO & & \\
\hline & Employees in HI & 47 & 3.34 \\
\hline & Academic public & 30 & 3.00 \\
\hline & Employees in TA & 38 & 2.76 \\
\hline & Total & 145 & 3.05 \\
\hline \multirow{5}{*}{ Competitiveness of prices in tourism. } & Employees in TO & 30 & 3.30 \\
\hline & Employees in HI & 47 & 3.38 \\
\hline & Academic public & 30 & 3.43 \\
\hline & Employees in TA & 38 & 2.84 \\
\hline & Total & 145 & 3.23 \\
\hline \multirow{5}{*}{$\begin{array}{l}\text { Tourism in Šumadija contributes to the preservation of the } \\
\text { environment. }\end{array}$} & Employees in TO & 30 & 3.13 \\
\hline & Employees in HI & 47 & 2.64 \\
\hline & \begin{tabular}{|l|} 
Academic public \\
\end{tabular} & 30 & 2.73 \\
\hline & Employees in TA & 38 & 2.26 \\
\hline & Total & 145 & 2.66 \\
\hline \multirow{5}{*}{$\begin{array}{l}\text { Tourism in Šumadija contributes to the greater living standard } \\
\text { of the population }\end{array}$} & Employees in TO & 30 & 2.87 \\
\hline & Employees in HI & 47 & 2.94 \\
\hline & Academic public & 30 & 3.47 \\
\hline & \begin{tabular}{|l|} 
Employees in TA \\
\end{tabular} & 38 & 2.68 \\
\hline & Total & 145 & 2.97 \\
\hline \multirow{5}{*}{$\begin{array}{l}\text { Tourism in Šumadija contributes to the preservation of social } \\
\text { values and tradition. }\end{array}$} & Employees in TO & 30 & 3.57 \\
\hline & Employees in HI & 47 & 3.62 \\
\hline & Academic public & 30 & 4.10 \\
\hline & Employees in TA & 38 & 3.29 \\
\hline & Total & 145 & 3.62 \\
\hline \multirow{5}{*}{$\begin{array}{l}\text { New knowledge, technologies, skills and training are } \\
\text { available to tourists in Šumadija. }\end{array}$} & Employees in TO & 30 & 3.07 \\
\hline & Employees in HI & 47 & 3.11 \\
\hline & Academic public & 30 & 3.10 \\
\hline & \begin{tabular}{|l|} 
Employees in TA \\
\end{tabular} & 38 & 2.50 \\
\hline & Total & 145 & 2.94 \\
\hline
\end{tabular}

Employees in HI - Employees in the hospitality industry, Employed in TA - Employees in the Travel Agencies, Employed in TO - Employees in the Tourism Organisations

Source: Authors, based on research

Based on the data from Table 3. it is noticeable that in relation to the observed attitude of the academic public, the mean is $\mathrm{M}=4.60$, while the other groups of respondents have an mean between 4.03 and 4.21. Thus, it can be concluded that, although there is a significant difference in the attitude of the academic public in relation to the other groups of respondents, all key stakeholders have a positive attitude towards the creation of the Sumadija tourist region, with the attitude of academic public showing as a highly positive. As for the next claim regarding natural attractions, we again see that the academic public has a separate and more positive attitude. When we look at the post hoc analysis of the claim about the quality of the facilities in tourism, we see that the opinion of those who are employed in tourist agencies differs from other stakeholders, 
and based on descriptive statistics we can conclude that they have a lower mean, significantly more negative attitude than other respondents. As for the claims on the traffic infrastructure, based on the post-hoc LSD analysis, we see that the attitude of the academic public in relation to employees in the hospitality industry and tourist agencies differs, and the descriptive statistics shows that they again have a more positive attitude than the other two groups of respondents. Regarding claims related to employed in tourism and hospitality in LSD post hoc analysis, we note that there is a disagreement between respondents employed in the hospitality industry and employees in tourist agencies (employees in tourist agencies have a significantly negative attitude towards this element of the tourist destination). As for the claims on the competitiveness of prices in tourism, the attitude of tourist agencies in relation to employees in the hospitality industry and the academic public is separated, and the descriptive statistics shows that they have a more negative attitude than the remaining two groups of stakeholders. Speaking about the claim that tourism in Šmadija contributes to the preservation of the environment in the post hoc analysis, we see that in this respect, the attitude of employees in tourist agencies is significantly different in relation to the attitudes of employees in tourist organizations and the academic public, and descriptive statistics shows that the groups of stakeholders have negative attitude (low means), except that it is significantly more negative in employees in tourist agencies. Regarding the views of the stakeholders regarding the claim that Tourism in Šumadija contributes to the living standards of the population and the preservation of social values and tradition as well as in the case of the first claim, the opinion of the academic public in relation to all other groups of stakeholders was more positive. When we look at the last claim that, according to the ANOVA analysis, there is a significant difference in the views of the respondents, that is, the new knowledge, technologies, skills and training are available to tourism stakeholders in Šumadija, there is a significant difference in the attitude of employees in tourist agencies, to all other stakeholders, i.e. their attitude to this issue is more negative in relation to all the other stakeholders.

We made a special post-hoc test for a claim that does not meet the test homogeneity of the variance, namely the Built and Cultural Tourist Attractions for which the GamesHowell test was performed, by which it was found that there is disagreement between the academic public and the employees in the hospitality industry. Descriptive statistics of the Games-Howell test shows that the academic public has the most positive, while hospitality industry employees have the most negative attitude on this issue.

In the continuation of the statistical analysis of the data obtained from the survey, we conducted an exploratory factor analysis. 
Table 4. Results of Factor Analysis

\begin{tabular}{|c|c|c|c|}
\hline F A C C T O R $\mathbf{R}$ & $\begin{array}{c}\text { Factor } \\
\text { loadings }\end{array}$ & $\begin{array}{l}\text { Eigen } \\
\text { values }\end{array}$ & $\begin{array}{c}\text { \% of } \\
\text { variance }\end{array}$ \\
\hline 1. Factor- SUSTAINABLE DEVELOPMENT & & 6.978 & 24.923 \\
\hline $\begin{array}{l}\text { Tourism in Šumadija contributes to a higher living standard of the } \\
\text { population. }\end{array}$ & 0.885 & & \\
\hline Tourism in Šumadija contributes to higher employment. & 0.882 & & \\
\hline $\begin{array}{l}\text { Tourism in Šmadija contributes to the development of the entire } \\
\text { economy. }\end{array}$ & 0.852 & & \\
\hline $\begin{array}{l}\text { Tourism in Šmadija contributes to the preservation of social } \\
\text { values and tradition }\end{array}$ & 0.715 & & \\
\hline $\begin{array}{l}\text { Tourism in Šmadija contributes to the preservation of the } \\
\text { environment. }\end{array}$ & 0.356 & & \\
\hline 2. Factor-COMPETITIVENESS & & 2.905 & 10.375 \\
\hline Traffic infrastructure and availability of tourist attractions. & 0.685 & & \\
\hline Competitiveness of prices in tourism. & 0.659 & & \\
\hline The employees in the tourism and hospitality industry. & 0.656 & & \\
\hline Quality of facilities in tourism (hotels, hostels, restaurants, etc.). & 0.629 & & \\
\hline 3. Factor- SPECIALIZATION & & 2.222 & 7.935 \\
\hline Rural tourism. & 0.784 & & \\
\hline $\begin{array}{l}\text { Cultural tourism (monasteries, churches, historical sites, museums, } \\
\text { exhibitions, etc.). }\end{array}$ & 0.725 & & \\
\hline $\begin{array}{l}\text { Mountain, sport and tourism of special interests (hunting, fishing, } \\
\text { recreation, wine tourism etc.). }\end{array}$ & 0.707 & & \\
\hline $\begin{array}{l}\text { City-break tourism and events (tour of Kragujevac and other } \\
\text { municipalities, festivals, concerts, etc.). }\end{array}$ & 0.634 & & \\
\hline Health and wellness tourism (spa and healing tourism). & 0.552 & & \\
\hline 4. Factor-REGIONALIZATION & & 1.777 & 6.348 \\
\hline $\begin{array}{l}\text { The promotion of Šumadija's destinations and attractions would } \\
\text { be more successful if Šumadija would be promoted as a special } \\
\text { tourist region. }\end{array}$ & 0.818 & & \\
\hline $\begin{array}{l}\text { Destinations in Šmadija will be more competitive if they function } \\
\text { as a special regional tourist destination (RTD). }\end{array}$ & 0.784 & & \\
\hline $\begin{array}{l}\text { If Šmadija could be constituted as a separate tourist region, it } \\
\text { would be easier to obtain the EU funds or other investments in } \\
\text { tourism. }\end{array}$ & 0.738 & & \\
\hline $\begin{array}{l}\text { Šmadija is a spatial entity with appropriate natural and created } \\
\text { tourist values in which a unified regional tourist product can be } \\
\text { formed. }\end{array}$ & 0.519 & & \\
\hline 5. Factor- INNOVATION & & 1.39 & 4.966 \\
\hline $\begin{array}{l}\text { Catering companies (hotels, hostels, restaurants, etc.) of Šumadija } \\
\text { have good websites. }\end{array}$ & 0.712 & & \\
\hline $\begin{array}{l}\text { The presence of catering companies (hotels, hostels, restaurants, } \\
\text { clubs) of Šumadija on key social networks is good and it helps to } \\
\text { increase tourist traffic. }\end{array}$ & 0.696 & & \\
\hline Business tourism (MICE). & 0.625 & & \\
\hline $\begin{array}{l}\text { Catering companies (hotels, hostels, restaurants, clubs) in } \\
\text { Šumadija are present on relevant tourist sites (booking.com, www. } \\
\text { tripadvisor.com, etc.). }\end{array}$ & 0.597 & & \\
\hline
\end{tabular}




\begin{tabular}{|c|c|c|c|}
\hline 6. Factor- ICT of Tourist organization & & 1.287 & 4.598 \\
\hline $\begin{array}{l}\text { The Tourist Organization (TO) Kragujevac helps and promotes all } \\
\text { other destinations in the Šumadija district }\end{array}$ & 0.847 & & \\
\hline $\begin{array}{l}\text { The information on the website of the Tourist Organization of the } \\
\text { City of Kragujevac (gtokg.org.rs) is of help to tourists who visit } \\
\text { this tourist region. }\end{array}$ & 0.774 & & \\
\hline $\begin{array}{l}\text { Information on the websites of other Tourism Organizations in } \\
\text { Šumadija (Arandjelovac, Topola, Rača, Knić, Lapovo, Batočina) } \\
\text { are of help to tourists who visit this tourist region. }\end{array}$ & 0.617 & & \\
\hline 7. Factor- Elements of tourist destination & & 1.131 & 4.041 \\
\hline Natural attractions (parks, rivers, lakes, mountains, climate). & 0.743 & & \\
\hline $\begin{array}{l}\text { Built and cultural tourist attractions (museums, theaters, galleries, } \\
\text { concerts, monuments, churches, monasteries, fairs and congresses } \\
\text { facilities etc.) }\end{array}$ & 0.666 & & \\
\hline $\begin{array}{l}\text { New knowledge, technologies, skills and training are available to } \\
\text { tourist entities in Šumadija. }\end{array}$ & 0.46 & & \\
\hline
\end{tabular}

Source: Authors, based on research

Based on the previous table (Table 4.), it can be noted that the respondents from the stakeholders' lines attach great importance to the sustainable development of tourism (describing almost $25 \%$ of the variance) as a base, but also to the factor of competitiveness (describing $10.4 \%$ of the variance), specialization and regionalization (describing 7.9, respectively $6.4 \%$ of the variance). Especially in the field of specialization, it is important to emphasize that the stakeholders give the greatest importance to rural, cultural and tourism of specific interests that are characteristic of rural areas in the Šumadija district. Especially with regard to regionalization, it is emphasized that Šumadija could be more easily promoted, but also be more competitive if it were established as a tourist region. ICT as the basis for innovation and smart specialization is not so important for stakeholders (describing about $5 \%$ of the variance). The situation is even worse when it comes to ICT available to tourist organizations in the Šumadija district (describing only $4.6 \%$ of the variance). Particularly worrying is the attitude of the stakeholders on the availability of new technologies, knowledge and skills related to tourism, where it could be concluded that according to the findings of factor analysis it is the weakest element of tourism in this part of Serbia.

\section{Conclusions}

By analyzing various scientific papers, as well as strategic and legal documents, we have found that defining Šumadija as a territorial unit of a lower level than the national varied in the number of municipalities and places it encompasses. The gravity center has always been Kragujevac, but there is a difference in what municipalities bind to themselves. Also, we could conclude that many of the most significant tourist attractions in Šumadija are located in the rural area, and that there is potential for the development of different forms of tourism, besides rural, primarily cultural and tourism of special interest.

Statistical research has shown that there is a very positive attitude that Šumadija should be established as a unique tourist region because all stakeholders have a positive attitude 
on this issue, with the attitude of the academic public as being very positive. In all other attitudes regarding regionalization in tourism, there is a high level of stakeholder agreement. We have also found that out of the 28 claims related to regionalization in tourism, competitiveness, innovation, sustainable development and smart specialization, in most cases there is a consensus of key stakeholders. There is no full consensus of the respondents in the ten claims. In particular, there is a disagreement about attitudes regarding the elements of competitiveness and sustainable development in the area of the Šmadija district. This particularly refers to the claim that Tourism in Sumadija contributes to the preservation of the environment that has the lowest means in all surveyed stakeholders, which means that they have the awareness that the principle of sustainable tourism development must be more respected. Also, based on the findings of descriptive statistics of the ANOVA test, we could conclude that the weakest element of the Sumadija tourist region is the traffic infrastructure, as well as the availability of modern technologies, knowledge and training.

Factor analysis has confirmed that the highest level of prioritization when it comes to tourism in the area of the Šumadija district has sustainable development, then competitiveness and specialization, but also regionalization. Issues such as innovation and ICT in tourism, are of lower priority level currently for stakeholders in Šmadija's tourism and as such cannot be the basis for the development of this segment of the economy, that is, much more investment is needed in order to keep up with the competition which precisely based on the development of ICT, creates its own competitive position. Further, this analysis has shown that the Šumadija tourist region should focus on rural and cultural tourism as the basis of its tourism product, as well as the tourism of special interests.

\section{Conflict of interests}

The authors declare no conflict of interest.

\section{References}

1. Bramwell, B. \& Lane, B.(1993). Sustainable Tourism:An Evolving GlobalApproach, Journal of Sustainable Tourism, 1(1), 1-5. DOI: 10.1080/09669589309450696

2. Bramwell, B. \& Lane, B. (2012). Towards innovation in sustainable tourism research?, Journal of Sustainable Tourism, 20(1), 1-7. DOI: 10.1080/09669582.2011.641559

3. Camisón C. \& Monfort-Mir V.M. (2012). Measuring innovation in tourism from the Schumpeterian and the dynamic-capabilities perspectives, Tourism Management, 33, 776-789. DOI: https://doi.org/10.1016/j.tourman.2011.08.012

4. Carlisle, S., Kunc, M., Jones, E. \& Tiffin, S. (2013). Supporting Innovation for Tourism Development Through Multi-Stakeholder Approaches. Tourism Management, 35(C), 59-69. DOI: https://doi.org/10.1016/j.tourman.2012.05.010

5. Charles, D., Gross, F.,\&Bachtler, J. (2012). "Smart specialization” and cohesion policy: a strategy for all regions?, IQ Net thematic paper, 30(2), European policies research centre. 
6. Council of Europe and prof. Gerard, M. (1998). Regionalisation and its effects on local self-government, Council of Europe Publishing, Strasbourg.

7. Цвијић, Ј. (1966). Балканско полуострво и јужнословенске земље. Народна библиотека, Београд. [in English: Cvijić, J. (1966). The Balkan Peninsula and the South Slavic countries. Narodna biblioteka, Belgrade.].

8. Dawkins, C. J. (2003). Regional Development Theory: Conceptual Foundations, Classic Works, and Recent Developments. Journal of Planning Literature, 18(2), 131-172. DOI: $10.1177 / 0885412203254706$

9. Decelle, X. (2006). A Dynamic Conceptual Approach to Innovation in Tourism, in Innovation and Growth in Tourism, OECD Publishing, Paris. pp. 85-106. DOI: https://doi.org/10.1787/9789264025028-en

10. Dimitrovski, D., Todorović A., \& Valjarević A. (2012). Rural tourism and regional development: Casestudy of development of rural tourism in the region of Gruža. Serbia, Procedia environmental sciences, 14, 288-297. DOI: 10.1016/j.proenv.2012.03.028

11. Divisekera, S., \& Nguyen, V.K. (2018). Determinants of innovation in tourism evidence from Australia, Tourism Management, 67, 157-167. DOI: 10.1016/j.tourman.2018.01.010

12. Đenadić, M., Muhi, B. \& Jovanovic, D. (2016). Rural tourism - Serbia’s missed chance. Economics of Agriculture, 2, 515-529.

13. European Commission (2012). Guide to Research and Innovation Strategies for Smart Specialization (Ris3), Publication Office of the European Union: European Commission, Luxemburg.

14. Градска туристичка организација Крагујевац (2014). Стратегија развоја туризма Града Крагујевияа 2015-2020, Крагујевац. [in English: Tourist organization of Kragujevac (2014). Tourism Development Strategy of the City of Kragujevac 2015-2020, Kragujevac.].

15. Foray, D., David, P. A., \& Hall, B. H. (2011). Smart specialization. From academic idea to political instrument, the surprising career of a concept and the dificulties involved in its implementation. MTEI-working paper, November 2011, Lausanne.

16. Foray, D. (2018). Smart specialization strategies as a case of mission-oriented policy-a case study on the emergence of new policy practices. Industrial and Corporate Change, 27(5), 817-832. DOI: https://doi.org/10.1093/icc/dty030

17. Hadjimichalis, C. \& Hudson, R. (2014). Contemporary Crisis Across Europe and the Crisis of Regional Development Theories, Regional Studies, 48(1), 208-218. DOI: $10.1080 / 00343404.2013 .834044$

18. Hall, C.M. (1996). Wine tourism in New Zealand, In Proceedings of Tourism Down Under 11: A Tourism Research Conference, pp. 109-119. University of Otago.

19. Hassink, R., \& Gong, H. (2019). Six critical questions about smart specialization, European Planning Studies. DOI: 10.1080/09654313.2019.1650898 
20. Higgins, B. \& Savoie, D.J. (2009). Regional development theories and their application, Transaction publishers, New Brunswick, USA. DOI: https:/doi. org/10.4324/9781315128269

21. Hjalager, A.M. (2010). A review of innovation research in tourism, Tourism Management, 31, 1-12. DOI: https://doi.org/10.1016/j.tourman.2009.08.012

22. Hjalager, A.M., \& Madsen, E.L. (2018). Business Model Innovation in Tourism: Opportunities, Challenges and Examples. In Cooper, C., Volo, S., Gartner, W.C. \& Scott, N. (Eds.) The Sage Handbook of Tourism Management (Vol. 1), Sage Publications Inc. Thousand Oaks, CA, pp 373-390.

23. Horwath consulting Zagreb (2005). Strategija turizma Republike Srbije. Ministarstvo trgovine, turizma i usluga Republike Srbije, Beograd. [in English: Horwath consulting Zagreb (2005). Tourism Strategy of the Republic of Serbia. Ministry of Trade, Tourism and Services of the Republic of Serbia, Belgrade.].

24. Јовановић, В. (2013). Тематски туризам. Универзитет Сингидунум, Београд. [in English: Jovanović, V. (2013). Thematic tourism. Singidunum University, Belgrade.].

25. Јовичић, Ж. (1994). Шумадија ичентрална област Србије. Српско географско друштво, Београд. [in English: Jovičić, Ž. (1994). Šumadija central region of Serbia. Serbian geographical society, Belgrade.]

26. Landabaso, M. (2014). Guest editorial on research and innovation strategies for smart specialisation in Europe, European Journal of Innovation Management, 17(4), 378 - 389. DOI: https://doi.org/10.1108/EJIM-08-2014-0093

27. Lane, B. (1994). What is rural tourism?, Journal of Sustainable Tourism, 2(1-2), 7-21. DOI: 10.1080/09669589409510680

28. Liu,Z. (2003). Sustainable Tourism Development: ACritique, Journal of Sustainable Tourism 11(6), 459-475. DOI: https://doi.org/10.1080/09669580308667216

29. MacDonald, R., \& Jolliffe, L. (2003). Cultural rural tourism: Evidence from Canada, Annals of Tourism Research, 30(2), 307-322. DOI:10.1016/S01607383(02)00061-0

30. Middleton, V.T.C. \& Hawkins, R. (2011). Sustainable Tourism: A Marketing Perspect. Routledge, New York, USA.

31. Milićević, S., Podovac, M., \& Čavlin, M. (2015). Resources for development of the Rača municipality as a rural tourism destination. Economics of Agriculture, 62(3), 751-765.

32. Министарство животне средине и просторног планирања Владе Републике Србије (2009). Стратегија просторног развоја Републике Србије 2009 - 2013 - 2020, Републичка агенција за просторно планирање, Београд. [in English: Ministry of Environment and Spatial Planning of the Government of the Republic of Serbia (2009). Spatial Development Strategy of the Republic of Serbia 2009 2013 - 2020, Republic Spatial Planning Agency, Belgrade.]. 
33. Mu, Z., Li, H., Jianhong, W., Ji, L., YanGeng, J., XiTing, L., Raj, R., \& Morpeth, N.D. (2007). Religious tourism and cultural pilgrimage: a Chinese perspective. In: Raj R. and Morpeth N.D. (Eds.) Religious tourism and pilgrimage festivals management: An International Perspective, CAB International, Wallingford UK, pp. 98-112. DOI: 10.1079/9781845932251.0098

34. Општина Кнић (2009). Стратегија одрживог развоја Опитине Кнић 2010 - 2020 година. Стална конференција градова и општина, Општина Кнић. [in English: Knić Municipality (2009). Sustainable Development Strategy of Knić Municipality 2010 - 2020. Standing Conference of Towns and Municipalities, Knić Municipality.].

35. Podovac, M., Đordević, N., \& Milićević, S. (2019). Rural tourism in the function of life quality improvement of rural population on Goč mountain. Economics of agriculture, 66(1), 205-220.

36. Регионална ангенција за економски развој Шумадије и Поморавља (2017). Стратегија одрживог развоја Општине Баточина 2017-2022, Општина Баточина. [in English: Regional Economic Development Agency for Šumadija and Pomoravlje (2017). Sustainable Development Strategy of Batočiina Municipality 2017-2022, Batočina Municipality.].

37. Регионална ангенција за економски развој Шумадије и Поморавља (2010) Стратегија одрживог развоја Општине Аранђеловац, Општина Аранђеловац. [in English: Regional Economic Development Agency for Sumadija and Pomoravlje (2010). Sustainable Development Strategy of Aranđelovac Municipality 20162021. year, Aranđelovac Municipality.].

38. Redžić, D. (2019). Religious tourism as a factor of tourism development in Greece: A case study of the monastery of St. Nektarios on Aegina. Hotel and Tourism Management, 7(1), 105-114. DOI: https://doi.org/10.5937/menhottur1901105R

39. Rinschede, G. (1992). Forms of Religious Tourism. Annals of Tounrm Research, 19, 51-67. DOI: 10.1016/0160-7383(92)90106-Y

40. Ritchie, J.R.B. \& Crouch, G.I. (2003). The Competitive Destination - A Sustainable Tourism Perspective, CABI Publishing, Wallingford UK.

41. Roberts, L., \& Hall, D. (2001). Rural Tourism and Recreation: Principles to Practice, CABI Publishing, New York.

42. Schrijver, F. (2005). Regionalism after regionalisation: Regional identities, political space and political mobilisation in Galicia, Brittany and Wales, Department of Geography, Planning and International Development Studies, University of Amsterdam.

43. Schumpeter, J. (1949). The Theory of Economic Development: An Inquiry into Profits, Capital, Credit, Interest, and the Business Cycle - third printing, Harvard University Press, Cambridge, Massachusetts.

44. Sigala, M., \& Leslie, D. (2005). International cultural tourism, management, implications and cases. Elsevier Butterworth-Heinemann, Oxford, UK. 
45. Söderbaum, F. (2003). Introduction: Theories of New Regionalism, in Söderbaum, F. i Shaw, T.M. (eds.) Theories of New Regionalism, pp. 1-21, Palgrave, Macillan, Hampshire, England. DOI: 10.1057/9781403938794

46. Testa, R., Galati, A., Schifani, G., Di Trapani, A.M., \& Migliore, G. (2019). Culinary tourism experiences in agri-tourism destinations and sustainable consumption - understanding Italian tourists' motivations. Sustainability, 11(17), 4588. DOI: https://doi.org/10.3390/su11174588

47. The International Ecotourism Society (TIES) https://ecotourism.org

48. Tourist organization of Kragujevac http://gtokg.org.rs

49. Tourist organization Oplenac Topola Municipality https://topolaoplenac.org.rs

50. Tourist organization of Rača Municipality http://tor.rs/sr

51. Васовић, М., и Јовичић, Ж. (1982). Важније туристичко-географске регије Eвропе. Рад, Београд. [in English: Vasović, M., \& Jovičić, Ž. (1982). Important tourist-geographical regions of Europe. Rad, Belgrade.].

52. Влада Републике Србије (1996). Закон о просторном плану Републике Србије, Службени Гласник Републике Србије 13/96. [in English: Government of the Republic of Serbia (1996). Spatial planning act of the Republic of Serbia, Official Gazette RS 13/96.].

53. Влада Републике Србије (2006). Уредба о управним окрузима. Службени Гласник Републике Србије 15/2006. [in English: Government of the Republic of Serbia (2006). Decree on administrative districts. Official Gazette RS 15/2006.].

54. Влада Републике Србије (2014). Уредба о утврђивању Регионалног просторног плана за подручје Шумадијског, Поморавског, Расинског и Рашког управног округа. Службени Гласник Републике Србије 39/2014. [in English: Government of the Republic of Serbia (2014). Decree on establishing the Regional Spatial Plan for the area Šumadijski, Pomoravski, Rasinski and Raški districts. Official Gazette RS 39/2014.].

55. Weiermair, K. (2006). Prospects for Innovation in Tourism: Analyzing the Innovation Potential Throughout the Tourism Value Chain, Journal of Quality Assurance in Hospitality \& Tourism, 6(3-4), 59-72. DOI: https://doi.org/10.1300/ J162v06n03_04

56. Yoder, J.A. (2003). Decentralisation and Regionalisation after Communism: Administrative and Territorial Reform in Poland and the Czech Republic, EuropeAsia studies, 55(2), 263-286. DOI: https://doi.org/10.1080/0966813032000055877

57. Живановић, 3. и Ђорђевић, А. (2012). О начину дефинисања (граница) функционално урбаних подручја у Србији, пример: Крагујевац, Демографија, 9, 147-166. [in English: Živanović, Z. \& Đorđević, A. (2012). About the method of defining (boundary) of functional urban areas in Serbia, for example: Kragujevac, Demographics, 9, 147-166.].

58. https://www.putvinasrbije.rs 